\title{
EXPLORACIONES LITERARIAS COMO FRUTOS EXTRAÑOS
}

Sobre Florencia Garramuño. Mundos en común. Ensayos sobre la inespecificidad del arte. Buenos Aires: Fondo de Cultura Económica, 2015. 226 pp.

Carolina Rolle

UNR

Mundos en común (2015) de Florencia Garramuño se compone de una serie de ensayos cuyas versiones preliminares fueron publicadas como artículos en Cuadernos, Boletines y Revistas académicas de reconocida trayectoria. Asimismo, existe una versión reducida de este libro publicada en portugués y editada en Rio de Janeiro por Rocco en 2014. En esta compilación -dividida en dos partes: "Prácticas de la no pertenencia" y "Singularidad sin pertenencia"- nos encontramos con lo que desde hace unos años es tema central de los estudios culturales: indagar sobre la (in)especificidad del arte y de la literatura. En el Arte fuera de sí (2004) -título que coincide con el de la introducción a La sociedad sin relato (2010) de Néstor García Canclini- Ticio Escobar plantea que la autonomia y la especificidad son nociones que no resultan suficientes a la hora de analizar las prácticas estéticas y las condiciones de productividad del arte contemporáneo. Y es en esta línea, a partir de la categoría del fuera de sí, que Florencia Garramuño propone en Mundos en común (2015) un dossier (prefiere esta categoría - por su carácter de inacabado- a la de corpus) de literatura y arte contemporáneos desde la no pertenencia a un arte o medio específico. 
En sintonía con su trabajo anterior: La experiencia opaca. Literatura y desencanto (Buenos Aires: FCE, 2009), Garramuño se interroga sobre el arte y la literatura a partir del surgimiento de escrituras y prácticas artísticas y culturales que ponen en discusión el concepto canónico de literatura y la noción de autonomía tanto en el campo de la literatura como en el del arte. Esto, a su vez, hace que se interrogue (exhaustivamente) en torno a los géneros, al sujeto y a lo que entendemos como lo real.

En Mundos en común se aleja de aquellas producciones argentinas y brasileñas de los años setenta y ochenta a las que en La experiencia opaca concibe como las primeras mutaciones, para detenerse en producciones latinoamericanas del presente más inmediato. Garramuño propone en Mundos en común lo que define como exploraciones literarias para dar cuenta de aquellos textos que establecen puntos de conexión y de fuga entre la ficción y las fotografías, las imágenes, las memorias autobiográficas, los blogs, los chats y los correos electrónicos, así como también de aquellos textos que se enmarcan entre el ensayo y lo documental; o bien aquellos que ponen en tensión los límites entre prosa y verso.

Para analizar esa puesta en crisis del medio específico recurre a obras tan diversas como las de Mario Bellatin, Bernardo Carvalho, João Gillberto Noll, Fernando Vallejo, Diamela Eltit, Luiz Ruffato, Tamara Kamenszain, Marcos Siscar, Martín Gambarrota, Carlito Azevedo y Nuno Ramos. Piensa a la literatura en ese más allá donde la escritura reaparece en formatos y soportes como el cine, el teatro o las instalaciones artísticas (analiza las obras de Nuno Ramos, Jorge Macchi, Rosangela Rennó, Ernesto Neto) y donde los diferentes lenguajes del arte dan cuenta de una gran porosidad de las fronteras entre los distintos campos de la estética. Así, construye un análisis de las prácticas estéticas latinoamericanas 
del presente y sus modos de habitar el mundo desde la transgresión y el desbordamiento de los límites de aquellos campos en los que las artes son entendidas como prácticas específicas. Estas prácticas en su fuera de si suponen una América Latina constituida por comunidades construidas en las fronteras y en los límites, imaginarios y reales, de tradiciones y de espacios, donde incluso se instala la imaginación de una nueva lengua. De esta manera, Garramuño construye una definición del potencial político del arte en el contexto de la cultura latinoamericana contemporánea.

Enmarcada en una línea posdeconstructivista, que entiende el arte desde una metodología teórica que se funda en el tránsito, en el pasaje, trabaja las tensiones de la prosa y la poesía que exhiben una reconfiguración del sujeto contemporáneo en pos de una exploración de la afectividad y de la intensidad de las emociones. Asimismo, reflexiona en torno al giro animal que se produce en las prácticas estéticas que ofrecen formas de imaginar nuevas virtualidades de lo inhumano y de sus comunidades posibles, a la vez que abre a la reflexión de nuevos modos de convivencia entre múltiples transformaciones y mutaciones. Por otra parte, Garramuño se pregunta acerca de aquellas obras -literarias (Martín Kohan y Alan Pauls) y plásticas (Macchi y Rennó)- que indagan en torno a la memoria y a las políticas del archivo y las trabaja no sólo como prácticas que desestabilizan totalidades o recomponen pasados, sino más bien como prácticas que insisten en hacer presente, exhibir, mostrar la materialidad de los restos, la conservación de los vestigios y residuos que generan otras historias, otras realidades construidas con fragmentos del pasado e impulsadas por estos pero que, a su vez, abandonan el pasado en favor de la presencia, la supervivencia de esos restos y el modo en que sus efectos perduran en el presente. Y en esta línea, propone pensar nuevos modos de reflexionar 
sobre los hechos y los acontecimientos históricos y contemporáneos.

Florencia Garramuño inscribe a la literatura y al arte en general en la figura de un arte inespecifico para explorar su no pertenencia no sólo a un medio sino también al interior de un mismo lenguaje, discurso y soporte. Según la autora, tanto en la literatura como en las obras plásticas o las instalaciones nada de lo propio les pertenece y para dar cuenta de esa puesta en crisis de las ideas de pertenencia y especificidad analiza la obra de Nuno Ramos como ejemplo paradigmático. Al tomar el caso de Fruto estranho -donde confluyen árboles, aviones, contrabajos, un loop de una escena de un filme de Ingmar Bergman de 1960 y la canción Strange Fruit interpretada por Billie Holiday- Garramuño observa el punto de fuga de lo propio y una expansión de los lenguajes artísticos que desborda los muros y las barreras de contención. Y en este entrecruzamiento de medios y soportes construye un discurso común -en tanto modo de existir y significar en comunidad- a esos objetos, materiales y mundos de referencias, en contra de la especificidad. Esta forma de concebir al arte desde el fuera de sí la autora lo emparenta a los postulados de Rosalind Krauss (1983) sobre la noción de campo expandido que ésta propone para situar la aparición de un nuevo tipo de obras artísticas que, para ser consideradas tales, exigían la construcción de una categoría infinitamente maleable. Garramuño lleva esta propuesta más allá para ponerla a funcionar -con sus connotaciones de implosiones internas y de constante reformulación y ampliación- sobre la mutación del arte contemporáneo (lo cual, claro está, incluye a la literatura). Dicha mutación en su inestabilidad y ebullición atenta contra la propia noción de campo como espacio estático y cerrado.

En consonancia con los cruces que presenta la obra de Ramos Fruto estranho, Florencia Garramuño propone a modo 
de cierre un dossier con variadas obras y prácticas a las que no se refirió explícitamente en el cuerpo argumentativo pero que le resultaron fundamentales para el desarrollo de sus reflexiones allí expuestas. A partir de la categoría de dossier, la autora abre el juego a la posibilidad de desplazar, transformar, modificar esta selección para motivar la reflexión y la construcción de nuevos interrogantes, de nuevos objetos de estudio. Se trata, como en las inclasificables instalaciones de Nuno Ramos, de textos literarios, obras plásticas, performances, instalaciones, archivos, que tensionan los límites de los medios, de los soportes, de los lenguajes, de los discursos. Y en este cruce se instala la imposibilidad de definir la especificidad en pos de construir una idea de una América Latina como espacio atravesado por heterogeneidades y múltiples transformaciones. Sin duda, Mundos en común hecha luz y abre puertas a futuras investigaciones. 